\title{
AZ ERDEI VÖRÖSHANGYÁK (FORMICA RUFA CSOPORT) ERDÖVÉDELMI SZEREPE EURÓPÁBAN - SZAKIRODALMI ÁTTEKINTÉS
}

\author{
Fürjes-Mikó Ágnes', Csősz Sándor² és Csóka György ${ }^{1}$ \\ ${ }^{1}$ NAIK Erdészeti Tudományos Intézet Erdővédelmi Osztály, Mátrafüred \\ ${ }^{2}$ MTA-ELTE-MTM Ökológiai Kutatócsoport
}

\begin{abstract}
Kivonat
Az erdei vöröshangyák generalista ragadozók. Tömegesen zsákmányolnak különféle herbivor rovarokat, miáltal jelentösen csökkenthetik azok népességét. Az erdei vöröshangya fajok táplálékukat elsősorban a fák lombkoronájában szerzik, ezáltal a lombfogyasztó rovarok számát hatékonyan csökkenthetik. Az európai irodalom meglehetösen tág határokat ad meg az erdei vöröshangyák táplálékspektrumára vonatkozóan. Vizsgálatok alapján az erdei vöröshangyák étrendjének csaknem felét rovarok, többek között erdészeti szempontból „kártevőknek” minősülő fajok teszik ki. Nagy mennyiségben fogyasztják továbbá a különböző növénytetü- és kabócafajok által termelt mézharmatot. A hangyák és a levéltetvek mutualista kapcsolatának a fák egészségét és növekedését érintő szerepe a mai napig nem egyértelműen tisztázott. Az erdei vöröshangya közösségek a talaj összetételére és szerkezetére is kedvező hatást gyakorolhatnak, fészekanyaguk ugyanis nagy mennyiségben és koncentráltan tartalmaz szerves anyagokat. Ezeket a fészekhez közeli fák hasznosítani tudják, ami serkentheti növekedésüket. Jelen közleményben az erdei vöröshangyák erdővédelmi szerepének hazai és európai szakirodalmát tekintjük át.
\end{abstract}

Kulcsszavak: erdei vöröshangya, erdőegészség, ragadozás, mézharmat, növénytetü-hangya mutualizmus, talajállapot.

\section{ROLE OF RED WOOD ANTS (FORMICA RUFA GROUP) IN FOREST PROTECTION IN EUROPE - A LITERATURE REVIEW}

\begin{abstract}
Red wood ants are generalist predators. They prey on many insect groups, so may significantly influence their abundance. Species in Formica rufa group obtain their food mainly from tree canopies, so they can effectively reduce the herbivore pressure. European literature gives wide ranges for their food spectra. Based on investigations, almost half of their food consists of insects, including species considered "forest pests". Honeydew of different Hemiptera species also plays an important role in their nutrition. The ant-aphid mutualistic relationship and its impacts on the health of trees and forests have been discussed for a long time. The ants may also have a positive effect on soil since their nest material contains concentrated minerals bound to organic materials. The trees near the nests can utilize these organic nutrients that can result in accelerated growth. In this paper we review the related Hungarian and European literature.
\end{abstract}

Keywords: red wood ants, forest health, predation, honeydew, aphid-ant mutualism, soil conditions. 


\section{BEVEZETÉS}

Egyre inkább nyilvánvaló, hogy a kedvezőtlen irányban változó környezeti viszonyok (klímaváltozás, biológiai inváziók) miatt az erdők egészségi állapotában további negatív változások várhatók. E kedvezőtlen folyamatok miatt egyes, tömegesen előforduló fajokra, mint az erdei vöröshangya populációkra várhatóan még az eddig feltételezettnél is jelentősebb szerep fog hárulni az erdők ellenálló- és visszaszerző-képességének visszaállításában, illetve erősítésében (Damien et al 2016, Fernandez-Conradi et al 2017, Jactel et al 2017). Ezek a ragadozók várhatóan kiemelt szerepet fognak játszani a növekvő erdei károk megelőzésében, illetve gyakoriságuk és mértékük csökkentésében.

A hangyák néhány kisebb sziget, valamint a sarkkörön túli területek kivételével a szárazföldeken mindenütt jelen vannak, és az élöhelyek legtöbbjében domináns szerepet töltenek be. A trópusi erdei közösségekben a hangyák az elhullott rovartetemek $60 \%$-ának eltávolításáért felelősek, és a ragadozási rátájuk meghaladja a kifejezetten ragadozó életmódra specializálódott pókokét is (Griffiths et al 2017). Szerepük európai közösségekben is kiemelkedő. Becslések szerint gyepeinkben a felszínen gyüjtögető hangyák biomasszájuk kétszázszorosát fogyasztják el (Way \& Khoo 1992), melynek túlnyomó többségét rovarok adják. A tevékenységük az erdei életközösségek müködésének szempontjából olyannyira meghatározó, hogy a hangyák kísérletes kizárása után nem marad olyan állatcsoport, amely a nagy mennyiségü rovar maradványt képes lenne eltávolítani, így azok nem tudnak visszakerülni a természetes körforgásba (Griffiths et al 2017).

Hazánkban ez idáig 126 hangyafaj előfordulása bizonyított (Csősz et al 2011). A hazai közösségek domináns fajai a vöröshangyák, vagyis a Formica s.str. szubgénusz fajai, amelyekröl köztudott, hogy tömegesen fogyasztanak fitofág rovarokat. Ezt számos európai, elsősorban közép-európai és északi területekről származó kutatás eredménye igazolja (Adlung 1966, Hölldobler \& Wilson 1990, Karhu \& Neuvonen 1998). Generalista táplálkozásuk miatt az erdei fákon táplálkozó rovarok széles körét is elejthetik. Mivel territóriumukat intenzíven védik, a területükön található növényeket képesek lehetnek megvédeni/megszabadítani a növényevő rovaroktól.

Jelen közleményben az erdei vöröshangyák erdővédelmi szerepének európai szakirodalmát szándékozunk áttekinteni, jelentős mértékben kibővítve két korábbi szakirodalmi áttekintésünket (Csóka \& Csősz 2014, Mikó \& Csóka 2016).

\section{GEOGRÁFIA ÉS TAXONÓMIA}

A Formica rufa csoport egy holarktikus elterjedésü fajcsoport, világviszonylatban 24 fajt sorolunk ide (Goropashnaya et al 2012). Európában mindössze 6 fajuk található (Goropashnaya et al 2004, Fleury et al 2010, Bernasconi et al 2011), amiböl hazánkban három faj (a Formica rufa (L, 1761), Formica polyctena (Foerster, 1850) és a Formica pratensis (Retzius, 
1783)) fordul elő (Csősz et al 2011). E fajok mindegyike népes, több tízezer dolgozót számláló kolóniákban él, és közös jellemzőjük, hogy növényi törmelékböl álló fészekdombot építenek. A Formica rufa csoport fajainak fészkében egy vagy több királynő is rakhat tojásokat, a többkirálynős kolóniákat polygín kolóniának is hívják (Fortelius 1993, Pamilo et al 1994, Gyllenstrand et al 2004). Egy kolónia kötődhet egy fészekhez (monodómia) vagy több fészek is tartozhat ugyanazon kolóniákhoz (polidómia), s ilyenkor gyakran a saját királynő, vagy királynők fészkeinek hálózata egy hatalmas szuperkolóniaként funkcionál: a dolgozók nem mutatnak agressziót a szomszédos fészkek lakóival, a táplálékforrás és az utódnevelés is közösen zajlik. Egy sok fészekböl álló szuperkolónia kiterjedése és egyedszáma óriásira nőhet. Az európai Formica lugubris (Zetterstedt, 1838) szuperkolóniái igen kiterjedtek lehetnek, territóriumuk akár 70 hektáros területet is lefedhet, melyben 1200 fészek található (Cherix 1980). A hazai erdeinkben is élő $F$. rufa faj esetében nem találkozunk ilyen extrém esetekkel, többnyire egyfészkes kolóniákat alkotnak, de a szuperkolóniáinak kiterjedése sem haladja meg a 11 hangyafészekböl álló rendszereket (Dekonick et al 2014). A F. polyctena nagy területet lefedő többfészkes kolóniákat alkot, a nagyobb fészkekhez közel kisebb fészkek is megfigyelhetőek, amelyeket úthálózat köt össze. A F. pratensis elsősorban nyilt füves területen, legelökön, kaszálókon fordul elö, de fészkei ritkán megfigyelhetőek erdőszéleken is. Erre a fajra is jellemző a többfészkes kolóniák létrehozása (Benedek 2012).

A csoport elkülönítésének nehézségeire jó példát szolgáltat a $F$. rufa és a $F$. polyctena fajpár esete. A két faj között a serték és szörszálak számában van statisztikailag kimutatható morfológiai különbség, tehát külső jellemzők alapján csak nagyon alapos mikroszkópos vizsgálattal különíthetök el (Seifert 1996, 2007). A fajok azonosítását tovább nehezíti az a tény, hogy egyes fajpárok, mint a F. rufa és a F. polyctena, (Seifert 1999, Seifert et al 2010, Sorvari 2006), vagy a Formica aquilonia (Yarrow, 1955) és a Formica paralugubris (Seifert, 1996) (Bernasconi et al 2010) egymással könnyen hibridizálódik. Az utóbbi időkben genetikai módszerek segítségével végeztek vizsgálatokat a fajok azonosítására (Bernasconi et al 2011). Ez a vizsgálat azt az eredményt hozta, hogy a hibridizációs problémáktól eltekintve a már említett 6 európai faj mindegyike különálló fajnak tekinthető, sőt, egy hetedik, morfológiailag a $F$. aquilonia-hoz megtévesztésig hasonlító, úgynevezett kriptikus faj jelenlétére is rámutatott. Ez az új, még leíratlan faj hazánkban nem fordul elő. Az említett európai taxonok csekély morfológiai eltérések mellett viselkedési jellemzőikben nagyon is eltérnek egymástól (Fleury et al 2010), és egyes kolóniák faji azonosítása a terepi, viselkedési vizsgálatok során gyakran könnyebben elvégezhető, mint a laborban, mikroszkóp alatt. A hibridek, illetve a kevert fajú egyedekből álló kolóniák nem csak morfológiai jellegeikben, hanem viselkedési vonásaikat tekintve is köztes helyet foglalnak el. Megfigyelték, hogy a $F$. rufa és $F$. polyctena nem csak hibrid utódokat hozhat létre, hanem allometrózis (különböző fajú egyedek együttes előfordulása egyazon kolóniában) is megfigyelhető náluk. Ezt a jelenséget elárvult, eltévedt egyedek befogadása mellett leginkább idegen fajba tartozó királynők adoptálása okozhatja (Czechowski 1996). 


\section{AZ ERDEI VÖRÖSHANGYÁK FŐBB TÁPLÁLÉKFORRÁSAI}

Az erdővédelmi szempontból jelentős vöröshangyafajok többsége mindenevő, általában a növényekhez kapcsolódó, növényeken található táplálékot fogyasztják (Way \& Khoo 1992). Az erdei vöröshangyák legjelentősebb táplálékai a rovarok és a mézharmat. A rovarokkal való táplálkozás késő tavasszal, kora nyáron történik, mert a hangyáknak ebben az időszakban van a legnagyobb szükségük fehérjére az utódgondozás sikere érdekében (Punttila et al 2004). A tavaszi intenzív rovarfogyasztást Ferrante és munkatársai (2014) is megfigyelték. Ez az időszak egyébként egybeesik a lomb- és a tülevélfogyasztó rovarlárvák (lepkehernyók, levéldarázs lárvák) tömeges megjelenésével. Késő nyáron inkább mézharmattal táplálkoznak (Carroll \& Janzen 1973), illetve akkor is, ha egyéb táplálék nem áll rendelkezésre (Way 1963). Az erdei vöröshangyák általában abbahagyják a mézharmat gyüjtését, amikor valamelyik rovar népessége ugrásszerüen megnövekszik (Wellenstein 1952).

Györfi (1957) szerint legnagyobb mértékben, 45\%-os arányban rovarokat, 42\%-ban levéltetü-váladékot (mézharmat), 6\%-ban kiszivárgó nedveket, 4\%-ban magvakat, 3\%-ban pedig gombákat és egyéb táplálékot fogyasztanak. Eidmann (1926) németországi (Babenhausen) vizsgálatai alapján az általuk fogyasztott állatok $42 \%$-a erdészeti szempontból kártevőnek minősülö, 28\%-a erdészetileg közömbös, 16\%-a erdészetileg hasznos rovar, a maradék 14\% nem meghatározható rovar. Wellenstein (1952) szerint táplálékuk 62\%-a mézharmat, 33\%-a rovar és 5\%-a gyanta, gomba, állati tetemek és magok. Skinner (1980) szerint a táplálékigényük $70 \%$-át a mézharmat teszi ki, ugyanakkor hangsúlyozza, hogy táplálék összetételük elsősorban attól függ, hogy milyen potenciális táplálék van nagy mennyiségben elérhető közelükben. Ezek az arányok jelentősen eltolódhatnak, például egy-egy táplálékul szolgáló rovar tömeges megjelenésekor, vagy ha a táplálékforrás közvetlenül a fészek közelében van, mert így nagyobb energia befektetés nélkül is táplálékhoz juthatnak. A hangyák nem mindegyik életciklusukban igényelnek nagy mennyiségü mézharmatot (Punttila et al 2004). Számukra léteznek alternatív cukorforrások is (pl. florális és extraflorális nektár), tehát a hangyák nincsenek mindig rászorulva a levéltetvek mézharmatára, bár számukra kétségkivül ez az egyik legjobb módja a táplálék biztositásának.

\section{AZ ERDEI VÖRÖSHANGYÁK ROVARPREDÁCIÓJA}

Az erdei vöröshangyák kiemelkedő erdővédelmi szerepének egyik oka, hogy nagyon nagy területen tudnak szuperkolóniákat létrehozni, így populációjuk igen népes lehet (Punttila et al 2004). A közösségekre gyakorolt hatásukat tovább fokozza, hogy éjjel és nappal is aktívak, és a táplálékul szolgáló rovarok minden fejlődési alakját, az erdő szinte minden szintjében zsákmányolják (Way 1963). Méretükböl adódóan is előnyt élveznek, mert a nagyobb méretű hangyák jellemzően nagyobb rovarokat ejtenek el (Savolainen 1990). Ered- 
ményességüket tovább fokozza, hogy egy fészek évekig egy helyen van, közvetlen kapcsolatban a körülötte található fákkal, ezáltal stabil táplálékszerzési rendszer tud kialakulni (Holt 1955).

Az erdei vöröshangyák generalista ragadozók, így más ízeltlábúak számát nagymértékben képesek csökkenteni az adott területen (Horák 2014). Ha több rovart pusztítanak el, mint amennyit a kolónia egyedei képesek elfogyasztani, akkor elraktározzák azokat. Az erdökben, tarrágás közben zölden maradó facsoportok (zöld szigetek) kialakulása mögött is az erdei vöröshangyák tevékenysége rejlik (Voute 1942). Valamilyen herbivor rovar tömeges fellépése során, a hangyafészkek vonzáskörzetében kevésbé károsított erdőfoltok figyelhetők meg, melyek a hangyák védelmének köszönhetően a nem, vagy csak kis mértékben károsodott lombkorona miatt zöldek maradnak. Győrfi (1957) ezeket a területeket „hangyabozótnak" nevezi. A hangyák predációja tehát kimutathatóan csökkenti a lombfogyasztó rovarok népességét, ennek köszönhetően a fák lombkoronájában kisebb mértékü lombvesztés következik be (Laine \& Niemelä 1980, Niemelä \& Laine 1986, Karhu 1998, Karhu \& Neuvonen 1998, Punttila et al 2004). A fészkektől távolodva, a hangyakolónia territóriumának széle felé, a lombvesztés mértéke folyamatosan növekszik (Adlung 1966). Ha viszont több kolónia territóriuma között átfedés van (pl. szuperkolóniák), akkor jóval kevesebb olyan terület van, ahol a növényekkel táplálkozó rovarok látványos lombvesztést okozhatnak.

Nem csak a hangyák aktív táplálékszerzése, de önmagában a hangyák jelenléte is védelmi funkcióval szolgálhat. Maňák $(2014,2015)$ kutatásai során megfigyelte, hogy az erdei vöröshangya ( $F$. rufa csoport) fészkek közelében a nagy fenyőormányos (Hylobius abietis) imágóinak kárositása kisebb, mert a hangyák jelenlétükkel zavarják az ormányos táplálkozását.

Annak ellenére, hogy az erdei vöröshangyák predációja széles körben kiterjed az erdei rovarokra, viszonylag kevés konkrét fajra vonatkozó adat áll rendelkezésre. Lepkék, legyek, bogarak, levéldarazsak, kabócák, poloskák, szöcskék és még sok más rovar mellett pókok és százlábúak is táplálékul szolgálhatnak számukra (Győrfi 1957, Adlung 1966). Bár a kemény, erősen kitinizált bogarakat és a szőrrel fedett lepkehernyókat nem tudják szájszervükkel megsebesíteni, hangyasavjuk segitségével a hangyák a cserebogarakat is képesek elpusztítani (Wellenstein 1957). A bogarak elejtésére vonatkozóan kevés információ áll rendelkezésre, egy közlemény említi, hogy néhány szúfaj is (Dendroctonus micans, Orthotomicus erosus, Ips sexdentatus, Ips typographus) szerepel zsákmány állataik között (Cilbircioğlu \& Ünal 2012).

A megfigyelések alapján az erdei vöröshangyák nagyon nagy mennyiségben fogyasztják az erdészeti szempontból kárositó rovarokat, azonban a számszerüsített adatok igen eltéröek. Az erdei vöröshangyák, különösen a $F$. rufa nagyon sok esetben fenyővel elegyes erdőkben fordul elő, ezáltal fenyőféléken élő rovarokat fogyaszthatnak, melyek gradációjakor a hangyák táplálékának akár $90 \%$-át is kitehetik (Bruns 1954). Egy közepes méretü $F$. polyctena kolónia egy év alatt 8000000 rovart ejthet el (Wellenstein 1952). Az erdei vöröshangyák ( $F$. polyctena) a fenyőbagoly (Panolis flammea) tojást rakó egyedeit, a fán és a talajon található lárváit, és a talajban található bábjait is elpusztítják (Way \& Khoo 1992). 
Mabelis 1979-ben számolt be arról, hogy araszoló lárvák (Geometridae) leptek el galagonya bokrokat. Néhány nap alatt az erdei vöröshangyák ( $F$. polyctena) útvonalat építettek ki, és szinte teljesen rovarmentessé tették ezeket a bokrokat.

Lucfenyő-levéldarazsak (Pristiphora abietina) esetében, egy 200000 dolgozóból álló $F$. rufa kolónia 1000-10 000 lárvát gyüjt naponta, egy 500000 dolgozóból álló kolónia akár 100000 darabot is. Egy 4 hetes gradáció során 1000000 lárvát is képesek kolóniánként összegyüjteni, ez az érték a kolónia méretétöl függ (Bruns 1954). Rust (1958) szerint tölgyiIonca (Tortrix viridana) károsítása során 400 kolónia több mint egymillió hernyót, és ezen kívül egyéb rovarokat is képes elfogyasztani. Hasonlóan ez előző esethez, egy 600 fészekből álló erdei vöröshangya szuperkolónia naponta 1000000 kis téliaraszoló (Operophtera brumata) és tölgyilonca (Tortrix viridana) lárvát gyüjt össze (Rust 1958). Fenyőbagoly ( $\mathrm{Pa}$ nolis flammea) erős gradációjakor az első hetekben az erdei vöröshangyák 112000 lárvát fogtak (Behrndt 1933, 1934), ami a többi adathoz viszonyitva kevés, bár ezt jelentősen befolyásolja a kolóniák mérete, a kártevőnek minősülő rovarok denzitása az adott területen, valamint ezeknek a rovaroknak a nagysága is.

Inozemtsev (1974) véleménye eltér számos kutatóétól azzal kapcsolatban, hogy az erdei vöröshangyák milyen mértékben generalisták, ugyanis szerinte a $F$. rufa válogat a táplálékforrások közül, a lepkék (Lepidoptera) és bogarak (Coleoptera) rendjébe tartozó rovarokat kedveli, és kevésbé kedveli a csigákat (Gastropoda), pókokat (Araneae), ugróvillásokat (Collembola), egyenesszárnyúakat (Orthoptera), hangyákat (Formicinae) és a félfedelesszárnyúakat (Hemiptera).

Az erdei vöröshangyák táplálékában kisebb arányban vannak jelen a ragadozó rovarok. Ennek nagy valószínüséggel az az oka, hogy az általában gyorsan mozgó ragadozókra nehezebb vadászniuk, mint a lassúbb fitofág rovarokra (Hartner 1994). Ugyanakkor megemlíthető, hogy generalista tulajdonságuk ellenére kisebb méretű rovarokat nem támadnak meg. Saját megfigyeléseink szerint pl. a tölgy-csipkéspoloska (Corythuca arcuata) tojásait, lárváit és imágóit akkor sem fogyasztották, amikor azok nagy számban voltak jelen, és közvetlen érintkezésbe kerültek a hangyákkal.

Eidmann (1926) megfigyelései alapján a hangyafészkekben ( $F$. rufa csoport) nagyon sok bogárfaj maradványa megtalálható (pl. Melolonthidae, Carabidae család fajai), azonban nem egyértelmű, hogy valóban a hangyák ölték meg őket, vagy a már elpusztult egyedeket szállitották a fészkekbe. Megfigyeltük, hogy akár még kisebb hüllöket (pl. egy kb. $20 \mathrm{~cm}$ hosszú lábatlan gyíkot) is képesek elejteni.

A környezeti viszonyok nagymértékben befolyásolják az erdei vöröshangyák predációs aktivitását. Mivel ezek a fajok aktivitásukban erősen hőmérsékletfüggőek, a mérsékelt övben télen, vagy hüvös időben inaktívak (Adlung 1966, Greathead 1976). A túl alacsony hőmérséklet általában akadályozza a hangyák zsákmányszerzését. A Fekete-erdő hegyvidéki területein például egy $F$. polyctena kolónia nem táplálkozott fenyőtükrösmoly hernyókkal (Epinotia tedella). A moly lárvája ugyanis akkor tartózkodik a lucfenyők ágain, amikor a hangyák számára a hőmérséklet még túl alacsony ahhoz, hogy azok vadászni tudjanak. 
1. táblázat: Néhány erdővédelmi jelentőségű herbivor rovarfaj hangya ragadozói.

Table 1: Ant predators of some forest insect pests.

\begin{tabular}{|c|c|c|c|c|c|c|}
\hline Rend & Család & Zsákmány & Hangyafaj & Fafaj & Stádium & Forrás \\
\hline \multirow{11}{*}{ Hymenoptera } & \multirow{5}{*}{ Diprionidae } & Diprion pini & F. poly & Pinus & $L$ & $1,2,3$ \\
\hline & & Gilpinia frutetorum & F.r. csop & & $L$ & 3 \\
\hline & & Gilpinia pallida & F.r. csop & & $L$ & 3 \\
\hline & & \multirow{2}{*}{ Neodiprion sertifer } & F.r. & Picea & $L$ & 4,5 \\
\hline & & & F.r. csop & Picea & $\mathrm{L}$ & 6 \\
\hline & \multirow{2}{*}{ Pamphiliidae } & Cephalcia abietis & F. poly & Picea & $L, I$ & 7 \\
\hline & & Neurotoma flaviventris & F.r. csop & & $\mathrm{L}$ & 3 \\
\hline & \multirow{4}{*}{ Tenthredinidae } & Mesoneura opaca & F.r. csop & Quercus & $\mathrm{L}$ & SA \\
\hline & & Pachynematus scutellatus & F.r. csop & Larix & $L$ & 8 \\
\hline & & \multirow{2}{*}{ Pristiphora abietina } & Fr. csop & Pinus & $L, B$ & $9,10,11$ \\
\hline & & & F. poly & Pinus & $\mathrm{L}$ & 12 \\
\hline \multirow{16}{*}{ Lepidoptera } & \multirow{2}{*}{ Coleophoridae } & \multirow{2}{*}{ Coleophora laricella } & F. lug & Larix & $\mathrm{B}, \mathrm{I}$ & 13 \\
\hline & & & F. nigr & Larix & $L$ & 14 \\
\hline & \multirow{5}{*}{ Erebidae } & Calliteara pudibunda & F. poly & Fagus & $L$ & 15 \\
\hline & & \multirow{2}{*}{ Lymantria dispar } & F. poly & Quercus & $L$ & $16, \mathrm{SA}$ \\
\hline & & & F.r. csop & Quercus & $\mathrm{L}$ & $17, \mathrm{SA}$ \\
\hline & & \multirow{2}{*}{ Lymantria monacha } & F.r. csop & Picea, Pinus & $B$ & 7,18 \\
\hline & & & F. poly & & & 16 \\
\hline & \multirow{5}{*}{ Geometridae } & Bupalus piniarius & F. poly & Pinus & $L, B, I$ & $3,16,19,20$ \\
\hline & & Entephria caesiata & F.r. csop & & L & 21 \\
\hline & & \multirow{2}{*}{ Epirrita autumnata } & F. aqu & Betula & L & $22,23,24,25,26$ \\
\hline & & & F.r. csop & Betula & L & 27 \\
\hline & & Operophtera brumata & F.r. csop & & $L$ & $28,29,30, \mathrm{SA}$ \\
\hline & Lasiocampidae & Dendrolimus pini & F.r. csop & Pinus & L & 20,31 \\
\hline & Noctuidae & Panolis flammea & F.r. csop & Pinus & $L, I$ & $7,15,32,33,34$ \\
\hline & Notodontidae & Thaumetopoea pityocampa & F.r. & Pinus & 1 & 13,35 \\
\hline & Tortricidae & Tortrix viridana & F.r. csop & Quercus & $L$ & $36,37,38,39, \mathrm{SA}$ \\
\hline \multirow{4}{*}{ Coleoptera } & \multirow{4}{*}{ Curculionidae } & Dendroctonus micans & \multirow{4}{*}{ F. $r$. } & \multirow{4}{*}{ Picea } & \multirow{4}{*}{ I } & \multirow{4}{*}{40} \\
\hline & & Orthotomicus erosus & & & & \\
\hline & & Ips sexdentatus & & & & \\
\hline & & Ips typographus & & & & \\
\hline
\end{tabular}

Röviditések/Abbreviations: F. poly- Formica polyctena; F.r. csop- Formica rufa csoport/group; F. r.- Formica rufa; F. lug- Formica lugubris; F. nigr- Formica nigricans; F. aqu- Formica aquilonia

A stádiumok rövidítései- L-lárva, B-báb; l-imágó

A hivatkozott irodalmi források rövidítései - 1: Goesswald 1940; 2: Wellenstein 1954; 3: Eidmann 1926; 4: Bruns 1954; 5: Bruns 1958; 6: Egger 1990; 7: Wellenstein 1957; 8: Voute 1951; 9: Bruns \& Schrader 1955; 10: Kolonits 1968; 11: Lindstedt et al 2006; 12: Kaitaniemi et al 2007; 13: Pavan 1961; 14: Schwenke 1957; 15: Zoebelein 1957; 16: Wellenstein 1959; 17: Györfi 1957; 18: Wellenstein 1942; 19: Goesswald 1941; 20: Goesswald 1951; 21: Linnaluoto \& Koponen 1980; 22: Laine \& Niemelä 1980; 23: Niemelä \& Laine 1986; 24: Karhu 1998; 25: Punttila et al 2004; 26: Karhu \& Neuvonen 1998; 27: Riihimäki et al 2005; 28: Rust 1958; 29: Skinner 1980; 30: Skinner \& Whittaker 1981; 31: Weckwerth 1952; 32: Behrndt 1933; 33: Behrndt 1934; 34: Singersberger \& Marcus 1937; 35: Pavan 1951; 36: Koenig 1956; 37: Goesswald 1958; 38: Otto 1958; 39: Otto 1959; 40: Cilbircioğlu \& Ünal 2012; SA: saját adat 
Adlung (1966) olyan esetről is beszámolt, amikor az erdei vöröshangyák annak ellenére sem fogyasztottak lucfenyő-levéldarázs (Pristiphora abietina) lárvákat, amikor ezresével voltak jelen a fészkek körül. Erdeifenyő-araszoló (Bupalus piniarius) esetében is történt ilyen, a $F$. rufa hangyák jelenléte ellenére sem történt predáció (Zoebelein 1954), pedig ezt a fajt a F. rufa csoport összes tagja zsákmányolja (Goesswald 1941, 1951, Wellenstein 1959). A hőmérséklet tehát nagymértékben befolyásolja az erdei vöröshangyák táplálkozási és zsákmányszerzési aktivitását. Néhány növény kémiai összetételének megváltozása is okozhatja a zsákmányolás csökkenését. Az erdei fenyők gyantasavat tartalmaznak, amennyiben ez a savtartalom magasabb koncentrációban van jelen, a hangyák kevésbé preferálják a fenyőn táplálkozó rovarokat (Larsson et al 1986).

Az 1. táblázatban összefoglaljuk azokat a szakirodalmi forrásokat, amik erdővédelmi jelentőségű rovarfajokat, és az azokat ragadozó erdei vöröshangya fajokat említenek.

\section{A HANGYA-NÖVÉNY-LEVÉLTETŰ KAPCSOLAT}

A hangyák leginkább közismert mutualista kapcsolata a Hemiptera fajokkal fenntartott viszony. Erdővédelmi szempontból azonban a legjelentösebb az erdei vöröshangyák és a levél-, valamint kéregtetvek közti kapcsolat. A hangyák csak ritkán táplálkoznak ezekkel a rovarokkal (Skinner 1980), viszont a mézharmatukat és egyéb mirigyváladékait rendszeresen fogyasztják (Way \& Khoo 1992). A kapcsolat mindkét fél számára pozitiv (Way 1963), mert a hangyák a táplálékhoz jutásuk közben megvédik a növénytetveket a különböző parazitoidoktól és predátoroktól (Hölldobler \& Wilson 1990, Schmutterer 1956), sőt ezáltal a növények is védelmet élveznek a hangyák jelenléte miatt (Beattie 1985). A hangyák szerepe azonban nem korlátozódik pusztán a védelemre. A mézharmat eltávolításával higiéniailag is fontos szerepet töltenek be, mert a felhalmozódó cukros váladék a kórokozók, például gombák elszaporodásának melegágya (Nielsen et al 2009). Arra csak a legutóbbi években derült fény, hogy a $F$. rufa csoport tagjai, a $F$. polyctena, a F. pratensis és a $F$. rufa képesek felismerni a rovarpatogén gombával (Beauveria bassiana) fertőzött levéltetű egyedeket, és azokat haladéktalanul el is távolítják a telepekről, meggátolva a fertőzés tovaterjedését. Ezek a fajok tehát aktívan hatást gyakorolnak a levéltetủ kolóniák állapotára (Novgorodova \& Kryukov 2017). Léteznek olyan valódi levéltetüfajok is (pl. Lachnus taeniatoides, Anuraphis farfarae, Byrsocrypta caerulescens), melyek a hangyák segítsége nélkül nem tudnak ürüléküktől megszabadulni (Győrfi 1957).

Az erdei vöröshangyák agresszív viselkedése megmutatkozhat a mézharmattal való táplálkozássukkal kapcsolatban is, hiszen képesek megakadályozni, hogy más rovar mézharmatot gyüjtsön a fákról (Karhu 1998). A katicabogárfélékkel szemben ez a viselkedés mind az imágók, mind a lárvák ellen megfigyelhető. A vöröshangya addig üldözi az ellenséget, míg meg nem öli, vagy az menekülésként le nem dobja magát a növényröl. Ennek eredményeképp a katicabogárfélék csak akkor próbálkoznak a hangyák által gondozott levéltetű 
telepeken táplálkozni, amikor a nem gondozott levéltetvekből hiány lép fel. Számos katicabogár-féle rendelkezik valamilyen védekezési stratégiával a hangyák agresszivitása ellen, melyek lehetnek viselkedésbeli, kémiai vagy fizikális formák (Selman 1988).

Az erdei vöröshangyák és a levéltetvek kapcsolatának a fák egészségére és növekedésére gyakorolt hatásának eredője igen sok tényezőtől függ, ezért nem lehet általános érvényüen kijelenteni, hogy ez a hatás pozitív vagy negatív (Whittaker \& Warrington 1985b, Mahdi \& Whittaker 1993). Kilpeläinen és munkatársai (2009) a Formica rufa csoport és Cinara fajok hatását vizsgálta különböző korú (5, 30, 60 és 100 éves) közönséges lucfenyő (Picea abies) állományokban. Az ötéves állományokban a látogatott fenyők magasságának éves növekedése 16,3\%-kal volt magasabb, mint ahonnan kizárták a hangyákat. Ez a különbség nem volt szignifikáns, viszont a 30 éves állományoknál szignifikánsan is kimutatható volt, hogy a fenyők átmérője 7,3\%-kal volt alacsonyabb a látogatott fákon. A 60 és 100 éves állományok esetében nem tapasztaltak számottevő különbséget.

Mahdi és Whittaker (1993) vizsgálatai alapján a hangyák jelenléte pozitív irányban befolyásolhatja a fák hajtásainak növekedését a levélvesztés csökkenésének köszönhetően. Sok esetben ugyanis az erdei vöröshangyák ( $F$. rufa) lombfogyasztók elleni védelme kompenzálja a levéltetvek hátrányos hatását a növényekre, sőt az állandóan a lombkoronában tartózkodó hangyák a különböző rovarfajok gradációjakor fellépő tarrágást is képesek megakadályozni.

A F.rufa által gondozott levéltetvek mézharmat termelése jóval magasabb, mint a nem gondozott levéltetveké. A sörtés juhar levéltetü (Periphyllus testudinaceus) például a F. rufa jelenlétében a nem gondozott levéltetvek mézharmat mennyiségének akár többszörösét is képes produkálni (Warrington \& Whittaker 1985a). A hangyák védelme a levéltetvek számát is megnöveli, a Symydobius oblongus egyedszáma például 82-szer magasabb azokon a nyírfákon, amelyeken F. lugubris hangyák is tartózkodnak (Fowler \& Macgarvin 1985).

A 2. táblázatban két vöröshangya faj a $F$. rufa (Skinner \& Whittaker 1981) és a $F$. lugubris (Breen 1979) fásszárúakon élő Hemiptera fajokkal való kapcsolatait mutatjuk be.

A hangyák és a növények kapcsolata több módon jöhet létre. A növények vonzhatják őket egyrészt direkt módon (nektár, táplálék), másrészt indirekt módon, különböző Hemiptera fajok mézharmat elöállitása miatt (Reyes-López \& Carpintero 2014). A növények is fontos közremüködői a rovarok közötti interakcióknak, valamint különböző szolgáltatásokat nyújtanak a hangyák számára. Példaként említhető, hogy a fészek felépítéséhez szükséges anyagokat szolgáltatnak. A növények is rendelkeznek védekező mechanizmusokkal, de a hangyák jelenléte jelentősen megnövelheti azok védettségét. White (1984) írta le a „növényistressz" teóriáját. Ha a növényt stressz hatás éri, a növény anyagcsere választ ad, fitokemikáliákat választ ki. Ezek a fitokemikáliák taszítják a fitofág rovarokat. Ilyen stresszfaktor a tápanyaghiány is, de ha van a közelben hangyafészek, amelynek köszönhetően nagyobb a tápanyag ellátottság és a fák fel tudják használni, akkor ez a növényi stressz a feltételezések szerint méginkább lecsökken a hangyafészkek közelében.

Mahdi és Whittaker (1993) vizsgálata alapján a különböző levélfogyasztó rovarok által elöidézett levélrágás hatszor nagyobb az erdei vöröshangyák ( $F$. rufa) által nem látogatott 
fákon, mint azokon, amelyeken megfigyelhetőek hangyák és levéltetvek is. Közönséges nyír (Betula pendula) csemeték is vizsgálat alá kerültek, és a hangyák által látogatott csemeték hajtásainak növekedése jóval nagyobb volt, mint a nem látogatott csemeték esetében.

Whittaker és Warrington (1985b) hegyi juhar (Acer pseudoplatanus) esetében vizsgálta hangyák és lombfogyasztó rovarok mennyiségének hatását a fák növekedésére. Azt tapasztalták, hogy a $F$. rufa hangyák által nem látogatott fák átmérőjének a növekedése 35-47\%kal kisebb volt, mint azoknak, amelyeken rendszeresen megfigyelhetőek voltak a hangyák. Csemeték esetében is tapasztalt eltéréseket. A vizsgálat mindhárom évében kisebb herbivor nyomás érte a látogatott csemetéket, és jóval nagyobb volt a tömegük és a friss hajtásaik mérete is, mint a nem látogatottaknak.

2. táblázat: Néhány fásszárúakon élő, erdei vöröshangyák által látogatott Hemiptera faj

( $\mathrm{SA}=$ saját adat)

Table 2: Some hemipterans, living on woody plants tended by red wood ants

( $S A=$ own data)

\begin{tabular}{|c|c|c|}
\hline Növénytetű faj & Tápnövény & Forrás \\
\hline \multicolumn{3}{|c|}{ Aphididae } \\
\hline Aphis sambuci & Sambucus & Skinner \& Whittaker 1981 \\
\hline Betulaphis quadrituberculata & Betula pendula & Skinner \& Whittaker 1981 \\
\hline Chaitophorus horii beuthami & Salix & Breen 1979 \\
\hline Periphillus testudinaceus & Platanus & Skinner \& Whittaker 1981 \\
\hline Symydobius oblongus & Betula pendula, B. pubescens & Breen 1979 \\
\hline Thelaxes dryophila & Quercus petraea & $\begin{array}{c}\text { Breen 1979, } \\
\text { Skinner \& Whittaker } 1981\end{array}$ \\
\hline Cinara abieticola (C. confinis) & Abies procera & Breen 1979 \\
\hline Cinara bogdanovi (C. pruinosa) & Picea abies, P. sitchensis & Breen 1979 \\
\hline Cinara kochiana & Larix decidua, L. kaemperi & Breen 1979 \\
\hline Cinara piceae & Picea sitchensis, P. abies & Breen 1979, SA \\
\hline Cinara pilicornis & Picea sitchensis, P. abies & Breen 1979 \\
\hline Cinara pinea & Pinus sylvestris & $\begin{array}{c}\text { Breen 1979, } \\
\text { Skinner \& Whittaker } 1981\end{array}$ \\
\hline Eulachnus brevipilosus & Pinus sylvestris & Breen 1979 \\
\hline Lachnus roboris & Quercus petraea & $\begin{array}{c}\text { Breen 1979, } \\
\text { Skinner \& Whittaker } 1981\end{array}$ \\
\hline Lachnus roboris & Quercus robur, Q. cerris & SA \\
\hline \multicolumn{3}{|c|}{ Psyllidae } \\
\hline Psylla crataegi & Crataegus & Skinner \& Whittaker 1981, SA \\
\hline
\end{tabular}




\section{A HANGYÁK HATÁSA A TALAJRA, A TALAJ FAUNÁJÁRA}

Az erdei hangyák a talaj tápanyagainak körforgásában, a talajjavításban, és az abba kerülő szerves anyagok feldolgozásában is részt vesznek (Gotwald 1986). A hangyák a járataik építése által lazítják, szellőztetik, összekeverik a talajt, így annak szerkezete javul. A mérsékelt égövön a hangyák talaj átforgató tevékenysége még a földigiliszták hasonló aktivitásán is túltesz (Seifert 1996). Egyes hangyafajoknak köszönhetően a fák tuskóinak szétrágása miatt a tuskók anyaga sokkal hamarabb kapcsolódik be a talaj tápanyag körforgalmába. A hangyák fészeképitése elősegitheti a sziklák begyepesedését is (Győrfi 1957).

Az erdei vöröshangyák a fészkek körül tápanyagokkal látják el a talajt, a hangyatetemek, a raktározott táplálék, és a hangyafészkek pusztuló anyaga nagy mennyiségben tartalmaz értékes, organikus tápanyagot, amely ezeken a területeken felhalmozódik, koncentrációja emelkedik. Ennek következtében a fészkekhez közel lévő fák levélvesztése csökken, mert hasznosítani tudják ezeket a forrásokat és jobb lesz a fák kondíciója (Karhu 1998). Laakso és Setälä (2000) vizsgálatai során azonban azt állapították meg, hogy a hangyák jelenléte nem befolyásolja a talaj mikrobiális jellemzőit, a talajban található ásványi anyagokat, és a növények növekedését sem.

A F. aquilonia hangyák a talajon tartózkodó rovarok (PI.: Carabidae) populációira negatív hatással vannak (Cherix \& Bourne 1980, Laakso \& Setälä 1998, Laakso 1999). Duma (2003) szerint a $F$. rufa jelenléte erősen befolyásolja a talaj gerinctelen élővilágát, azonban nem megszünteti, hanem lecsökkenti a denzitást a hangyák jelenléte, így a talajban más rovarok mellett is egyidejüleg lehetnek jelen. Laakso (1997) számolt be a $F$. aquilonia talajban élő állatokra gyakorolt hatásáról. A hangyák jelenlétében a pók (Araneae) és kaszáspók (Opiliones) fajok száma lecsökkent. Két földigilisztafaj, a Dendrodilus rubidus és a Dendrobaena octaedra kapcsolatát is vizsgálta, az előbbi reprodukciós teljesitménye megnőtt magas hangya denzitásnál, míg utóbbinál nem mutatott ki ilyen hatást. A földigiliszták biomasszája hétszeresére emelkedik a hangyafészkekben, ami annak köszönhető, hogy a gilisztáknak kedvez a fészkek hőmérséklete, páratartalma, savassága és táplálékkínálata (Laakso \& Setälä 1997). A talajban található Dendrobaena octaedra földigiliszta faj előfordulása 54\%-kal csökkent azokon a területeken, ahonnan a hangyafészkeket eltávolították (Laakso \& Setälä 2000).

\section{KÖSZÖNETNYILVÁNÍTÁS}

Jelen tanulmány az OTKA 128008 (Erdővédelmi jelentőségü ökoszisztéma szolgáltatások számszerüsítése magyarországi tölgyesekben) kutatási projekt keretében készült. 


\section{FELHASZNÁLT IRODALOM}

Adlung K.G. 1966: A critical evaluation of the European Research on use of red wood ants (Formica rufa group) for the protection of forests against harmful insects. Zeitschrift für Angewandte Entomologie 57: 167-189. DOI: $10.1111 /$ /.1439-0418.1966.tb03822.x

Beattie A. 1985: The evolutionary ecology of ant-plant mutualisms. Cambridge University Press, Cambridge. DOI: $10.1017 / C B 09780511721878$

Behrndt G. 1933: Die Bedeutung der Roten Waldameise bei Forleulenkalamitäten. Zeitschrift für Forst- und Jagdwesen 65: 479-498.

Behrndt G. 1934: Einige Beobachtungen über die Bedeutung von Formica rufa und $F$. fusca bei Forleulenkalamitäten. Forstarchiv 10(18): 289-294.

Benedek K. 2012: Territoriális Formica fajok fészekkomplexumainak szerveződése és közösségszervező hatása. Doktori értekezés. Szegedi Tudományegyetem. DOI: 10.14232/phd.1572

Bernasconi C., Pamilo P. \& Cherix D. 2010: Molecular markers allow sibling species identification in red wood ants (Formica rufa group). Systematic Entomology 35(2): 243-249. DOI: 10.1111/j.13653113.2009.00503.x

Bernasconi C., Cherix D. \& Pamilio P. 2011: Molecular taxonomy of the Formica rufa group (red wood ants) (Hymenoptera: Formicidae): a new cryptic species in the Swiss Alps? Myrmecological News 14: 37-47.

Breen J. 1979: Aphids visited by Formica lugubris (Hymenoptera: Formicidae) including eleven species new to Ireland. Irish Naturalists' Journal 19: 349-352.

Bruns H. 1954: Beobachtungen zum Verhalten der Roten Waldameise während des Nahrungserwerbes. Zeitschrift für Tierpsychologie 11(1): 151-154. DOI: 10.1111/j.1439-0310.1954.tb02042.x

Bruns H. \& Schrader A. 1955: Abnahme der Kokondichte der Roten Kiefernbuschhornblattwespe (Neodiprion sertifer) bei Nestern der Roten Waldameise. Waldhygiene 1: 33-68.

Bruns H. 1958: Untersuchungen und Beobachtungen an einer Naturkolonie der Roten Waldameise (Formica rufa) im Schadgebiet der Kl. Fichtenblattwespe (Pristiphora abietina). Zeitschrift für Angewandte Entomologie 43(3): 326-335. DOI: 10.1111/j.1439-0418.1958.tb01328.x

Carroll C.R. \& Janzen D.H. 1973: Ecology of foraging by ants. Annual Review of Ecology and Systematics 4: 231-257. DOI: $10.1146 /$ annurev.es.04.110173.001311

Cherix D. \& Bourne J.D. 1980: A field study on a supercolony of the red wood ant Formica lugubris in relation to the predatory arthropods (spiders, harvestmen and ants). Revue Suisse de Zoologie 87: 955-973. DOI: 10.5962/bhl.part.85566

Cherix D. 1980: Note préliminaire sur la structure, la phenologie et le régime alimentarie d'une super-colonie de Formica lugubris Zett. Insectes Sociaux 27: 226-236. DOI: $10.1007 /$ bf02223666

Cilbircioğlu C. \& Ünal S. 2012: Bark beetles and their natural enemies on oriental spruce from the black sea region of Turkey. Journal of Agricultural and urban Entomology 28: 42-56. DOI: 10.3954/1523-547528.1.42

Csóka Gy. \& Csősz S. 2014: Hangyák és a holtfa. In: Csóka Gy. \& Lakatos F. (eds): A holtfa. Silva naturalis, 5: 109-114.

Csősz S., Markó B. \& Gallé L. 2011: The myrmecofauna (Hymenoptera: Formicidae) of Hungary: an updated checklist. North-Western Journal of Zoology 7(1): 55-62.

Czechowski W. 1996: Colonies of hybrids and mixed colonies; interspecific nest takeover in wood ants (Hymenoptera, Formicidae). Memorabilia Zoologica, 50.

Damien M., Jactel H., Meredieu C., Régolini M., Van Halder I. \& Castagneyrol B. 2016: Pest damage in mixed forests: Disentangling the effects of neighbor identity, host density and host apparency at different spatial scales. Forest Ecology and Management 378: 103-110. DOI: 10.1016/.j.foreco.2016.07.025

Dekoninck W., Maebe K., Breyne P. \& Hendrick F. 2014: Polygyny and strong genetic structuring within an isolated population of the wood ant Formica rufa. Journal of Hymenoptera Research 41: 95-111. DOI: 10.3897/JHR.41.8191 
Duma I. 2003: The impact of red wood ants Formica rufa on the distribution of invertebrate fauna from the forest's floor (I). Annals of West University of Timisoara: Series of Biology 5-6: 121-130.

Egger A. 1990: Künstliche Ameisenvermehrung der Formica polyctena Foerst. (Kleine Waldameise) über Ablegerbildung in Oberösterreich. Waldhygiene 18(3-4): 65-92.

Eidmann H. 1926: Die forstliche Bedeutung der Roten Waldameise. Zeitschrift für Angewandte Entomologie 12(2): 298-331. DOI: 10.1111/j.1439-0418.1927.tb00274.X

Fernandez-Conradi P., Borowiec N., Capdevielle X., Castagneyrol B., Maltoni A., Robin C., et al. 2017: Plant neighbour identity and invasive pathogen infection affect associational resistance to an invasive gall wasp. Biological Invasions 20: 1459-1473. DOI: 10.1007/s10530-017-1637-4

Ferrante M., LoCacciato A. \& Lövei G. L. 2014: Quantifying predation pressure along an urbanisation gradient in Denmark using artificial caterpillars. European Journal of Entomology 111(5): 649-654. DOI: 10.14411/eje.2014.082

Fleury M., Bernasconi C., Freitag A., Pamilo P. \& Cherix D. 2010: Behavioural species discrimination in red wood ants (Formica rufa group). eco. mont Journal on Protected Mountain Areas Research 2: 13-20. DOI: 10.1553/eco.mont-2-2s13

Fortelius W., Rosengren R., Cherix D. \& Chautems D. 1993: Queen recruitment in a highly polygynous supercolony of Formica lugubris (Hymenoptera, Formicidae). Oikos 193-200. DOI: 10.2307/3545463

Fowler S.V. \& Macgarvin M. 1985: The impact of hairy wood ants, Formica lugubris, on the guild structure of herbivorous insects on birch, betula pubescens. Journal of Animal Ecology 54(3): 847-855. DOI: $10.2307 / 4382$

Goesswald K. 1940: Beobachtungen über den Schutz eines Kieferbestandes vor der Kiefernbuschhornblattwespe durch die Roten Waldameise. Zeitschrift für Forst- und Jagdwesen 72(2): 370-378.

Goesswald K. 1941: Ist nun die Rote Waldameise nützlich oder scähdlich? Anzeiger für Schädlingskunde 17(1): 1-7. DOI: $10.1007 / \mathrm{bf02338045}$

Goesswald K. 1951: Die Rote Waldameise im Dienste der Waldhygiene. Forstwirtschaftliche Bedeutung, Nutzung, Lebensweise, Zucht, Vermehrung und Schutz. Kinau Verlag, Lüneburg.

Goesswald K. 1958: Weitere Beobachtungen über die Auswirkung der Roten Waldameise auf den Eichenwickler. Waldhygiene 2: 143-153.

Goropashnaya A.V., Fedorov V.B. \& Pamilo P. 2004: Recent speciation in the Formica rufa group ants (Hymenoptera, Formicidae): interference from mithocondrial DNA phylogeny. Molecular Phylogenetics and Evolution 32(1): 198-206. DOI: 10.1016/i.ympev.2003.11.016

Goropashnaya A.V., Fedorov V.B., Seifert B. \& Pamilo P. 2012: Phylogenetic relationships of palaearctic Formica species (Hymenoptera, Formicidae) based on mitochondrial cytochrome b sequences. PLoS ONE 7(7): e41697. DOI: $10.1371 /$ journal.pone. 0041697

Gotwald W.H. 1986: The beneficial economic role of ants. In: Vinson S.B. (ed): Economic Impact and Control of Social Insects New York: Praeger Scientific, 290-313.

Greathead D.J. 1976: A review of biological control in western and southern europe. Technical Communications of Commonwealth Institute of Biological Control, No. 7 Farnham: CIBC, 182 p.

Győrfi J. 1957: Erdészeti rovartan. Akadémiai Kiadó, Budapest, 126-127.

Griffiths H.M., Ashton L.A., Walker A.E., Hasan F., Evans T.A., Eggleton P., et al. 2017: Ants are the major agents of resource removal from tropical rainforests. Journal of Animal Ecology 87: 293-300. DOl: 10.1111/1365-2656.12728

Gyllenstrand N., Seppä P. \& Pamilo P. 2004: Genetic differentation in sympatric wood ants, Formica rufa and F. polyctena. Insectes Sociaux 51: 139-145. DOI: 10.1007/s00040-003-0720-2

Hartner A. 1994: Formicoidea vizsgálatok Nyugat- és Dél-dunántúli erdőkben. Kandidátusi értekezés.

Holt S.J. 1955: On the foraging activity of the wood ant. Journal of Animal Ecology 24: 1-34. DOI: $10.2307 / 1877$

Horák J. 2014: Introduction to forest protection. Faculty of Forestry and Wood Sciences, CULS Prague.

Hölldobler B. \& Wilson E.O. 1990: The Ants. Harvard University Press, Cambridge.

Inozemtsev A.A. 1974: Dinamika troficheskikh svyazey ryzikh lesnykh murav'ev i ikh rol'v regulyatsii chislennosti vrednykh bespozvonochnykh v dubravakh Tul'skoy oblasi. Ekologiya 3: 63-71. 
Jactel H., Bauhus J., Boberg J., Bonal D., Castagneyrol B., Gardiner B., et al. 2017: Tree Diversity Drives Forest Stand Resistance to Natural Disturbances. Current Forestry Reports 3: 223-243. DOI: 10.1007/s40725-017-0064-1

Kaitaniemi P., Riihimäki J., Koricheva J. \& Vehviläinen H. 2007: Experimental evidence for associational resistance against european pine sawfly in mixed tree stands. Silva Fennica 41(2): 259-268. DOI: $10.14214 / \mathrm{sf} .295$

Karhu K. \& Neuvonen S. 1998: Wood ants and a geometrid defoliator of birch: predation outweights beneficial effects through the host plant. Oecologia 113: 509-516. DOI: $10.1007 /$ s004420050403

Karhu K. 1998: Green Islands- top-down and bottom up effects of wood ants in forests under folivore attack. Annales Universitatis Turkuensis.

Kilpeläinen J., Finér L., Neuvonen S., Niemelä P., Domisch T., Risch A.C., et al. 2009: Does the mutualism between wood ants (Formica rufa group) and Cinara aphids affect Norway spruce growth? Forest Ecology and Management 257: 238-243. DOI: 10.1016/j.foreco.2008.08.033

Koenig H. 1956: Über die Auswirkungen künstlicher Vermehrung der Kl. Roten Waldameise im Staatlichen Forstamt Münster. Waldhygiene 1: 227-229.

Kolonits J. 1968: A fenyőrontó darázs (Neodiprion sertifer Geoffr.) elleni védekezési eljárások. In: Keresztesi B. (ed): Erdészeti Kutatások. Az Erdészeti Tudományos Intézet közleményei, Debrecen.

Laakso J. \& Setälä H. 1997: Nest mounds of red wood ant (Formica aquilonia): hot spots for litter dwellingearthworms. Oecologia 111: 565-569. DOI: 10.1007/s004420050272

Laakso J. \& Setälä H. 1998: Composition and trophic structure of detrital food web in ant nest mounds of Formica aquilonia and in the surrounding forest soil. Oikos 81: 266-278. DOI: $10.2307 / 3547047$

Laakso J. 1999: Short-term effects of wood ants (Formica aquilonia Yarr.) on soil animal community structure. Soil Biology and Biochemistry 31: 337-343. DOI: 10.1016/S0038-0717(98)00131-X

Laakso J. \& Setälä H. 2000: Impacts of wood ants (Formica aquilonia Yarr.) on the invertebrate food web of the boreal forest floor. Annales Zoologici Fennici 37: 93-100.

Laine K.J. \& Niemelä P. 1980: The influence of ants on the survival of mountain birches during an Oporinia autumnata (Lep., Geometridae) outbreak. Oecologia 47: 39-42. DOI: 10.1007/bf00541773

Larsson S., Björkman C. \& Gref R. 1986: Responses of Neodiprion sertifer (Hym., Diprionidae) larvae to variation in needle resin acid concentration in Scots pine. Oecologia 70: 77-84. DOI: $10.1007 / \mathrm{BF} 00377113$

Lindstedt C., Mappes J., Päivinen J. \& Varama M. 2006: Effects of group size and pine defence chemicals on Diprionid sawfly survival against ant predation. Oecologia 150: 519-526. DOI: 10.1007/s00442-006-0518$\underline{9}$

Linnaluoto E.T. \& Koponen S. 1980: Lepidoptera of Utsjoki, northernmost Finland. Kevo Notes 5: 1-68.

Mabelis A.A. 1979: Wood ant wars - The relationship between aggression and predation in the red wood ant (Formica polyctena Först). Netherlands Journal of Zoology 29(4): 451-620. DOI: $\underline{10.1163 / 002829679 X 00016}$

Mahdi T. \& Whittaker J.B. 1993: Do birch trees (Betula pendula) grow better if foraged by wood ants? Journal of Animal Ecology 62: 101-116. DOI: 10.2307/5486

Maňák V. 2014: Interactions between ants and pine weevils - Effect on forest regeneration. Doctoral thesis Swedish University of Agricultural Sciences, Uppsala.

Maňák V., Björklund N., Lenoir L. \& Nordlander G. 2015: The effect of red wood ant abundance on feeding damage by the pine weevil Hylobius abietis. Agricultural and Forest Entomology 17: 57-63. DOI: 10.1111/afe. 12080

Mikó Á. \& Csóka Gy. 2016: A hangyák szerepe a magyarországi erdei ökoszisztémákban. In: Korda M. (ed): Az erdőgazdálkodás hatása az erdők biológiai sokféleségére. Tanulmánygyüjtemény. Duna-Ipoly Nemzeti Park Igazgatóság, 109-128.

Nielsen C., Agrawal A.A. \& Hajek A.E. 2009: Ants defend aphids against lethal disease. Biology letters 6(2): 205-208. DOI: $10.1098 / \mathrm{rsbl} .2009 .0743$

Niemelä P. \& Laine K. 1986: Green islands-predation not nutrition. Oecologia 68: 476-478. DOI: $\underline{10.1007 / B F 01036758}$ 
Novgorodova T.A. \& Kryukov V.Y. 2017: Quarantining behaviour of ants towards infected aphids as an antifungal mechanism in ant-aphid interactions. Entomologia Experimentalis et Applicata 162(3): 293-301. DOI: $10.1111 /$ eea.12552

Otto D. 1958: Zur Schutzwirkung der Waldameisenkolonien gegen Eichenschädlinge. Waldhygiene 2: 137142.

Otto D. 1959: Der Einfluß von Waldameisenkolonien auf Eichenschadinsekten in einem Forstrevier des nördlichen Harzrandes. Waldhygiene 3(3-4): 65-93.

Pamilo P., Sundström L., Fortelius W. \& Rosengren R. 1994: Diploid males and colony-level selection in Formica ants. Ethology Ecology \& Evolution 6: 221-235. DOI: 10.1080/08927014.1994.9522996

Pavan M. 1951: Primi resultati di un esperimento pratico di lotta biologica con Formica rufa L. contro Processionaria del pino (Thaumetopoea pityocampa Schiff.). Atti della Società italiana di scienze naturali 90: 112.

Pavan M. 1961: Formica lugubris Zett. predatrice della Coleophora laricella Hb. (Lep. Coleoph.). Notiziario For. e. Montani 6(91-92): 2920-2921.

Pell J.K., Baverstock J., Roy H.E., Ware R.L. \& Majerus M.E.N. 2007: Intraguild predation involving Harmonia axyridis: a review of current knowledge and future perspectives. BioControl 53(1): 147-168. DOI: 10.1007/978-1-4020-6939-0_10

Punttila P., Niemelä P. \& Karhu K. 2004: The impact of wood ants (Hymenoptera: Formicidae) on the structure of invertebrate community on mountain birch (Betula pubescens ssp. czerepanovii). Annales Zoologici fennici 41: 429-446.

Reyes-López J. \& Carpintero S. 2014: Comparison of the exotic and native ant communities (Hymenoptera: Formicidae) in urban green areas at inland, coastal and insular sites in Spain. European Journal of Entomology 111(3): 421-428. DOI: 10.14411/eje.2014.044

Riihimäki J., Kaitaniemi P., Koricheva J. \& Vehviläinen H. 2005: Testing the enemies hypothesis in forest stands: the important role of tree species composition. Oecologia 142: 90-97. DOI: 10.1007/s00442-0041696-y

Rust E. 1958: Aufbau der ersten Ameisenfarm. Forst und Jagd 8: 131-135.

Savolainen R. 1990: Interference by wood ant influences size selection and retrieval rate of prey by Formica fusca. Behavioral Ecology and Sociobiology 28: 1-7. DOI: 10.1007/BF00172132

Schmutterer H. 1956: Saugschäden an Eichen und Buchen durch Lachniden in Abhängigkeit von AmeisenTrophobiose. Zeitschrift für Angewandte Entomologie 39(2): 178-185. DOI: 10.1111/j.14390418.1956.tb01249.x

Schwenke W. 1957: Über die räuberische Tätigkeit von Formica rufa L. and F. nigricans Emery außerhalb einer Insektenmassenvermehrung. Beitrage zur Entomologie 7(3-4): 226-246.

Seifert B. 1996: Ameisen beobachten, bestimmen. Naturbuch Verlag Augsburg.

Seifert B. 1999: Interspecific hybridisations in natural populations of ants by example of a regional fauna (Hymenoptera, Formicidae). Insectes Sociaux 46(1): 45-52. DOI: 10.1007/s000400050111

Seifert B. 2007: Die Ameisen Mittel- und Nordeuropas. Lutra Verlag-u. Vertriebsges.

Seifert B., Kulmuni J. \& Pamilo P. 2010: Independent hybrid populations of Formica polyctena X rufa wood ants (Hymenoptera: Formicidae) abound under conditions of forest fragmentation. Evolutionary Ecology 24(5): 1219-1237. DOI: $10.1007 / \mathrm{s} 10682-010-9371-8$

Selman B.J. 1988: Chrysomelids and ants. In: Jolivet P., Petitpierre E. \& Hsiao T.H. (eds): Biology of Chrysomelidae. Kluwer Academic Publishers, 463-473. DOI: 10.1007/978-94-009-3105-3_27

Sindersberger M. \& Marcus B.A. 1937: Das Auftreten der Forleule in Mittelfranken. Mitteil. Bavarian Staatsforstverwaltung H. 22: 11-18.

Skinner G.J. 1980: The feeding habits of the wood ant Formica rufa (Hymenoptera: Formicidae) in limestone woodland in north west England. Journal of Animal Ecology 49: 417-433. DOI: 10.2307/4255

Skinner G.J. \& Whittaker J.B. 1981: An experimental investigation of the inter-relationships between the wood ant (Formica rufa) and some tree-canopy herbivores. Journal of Animal Ecology 50: 313-326. DOI: $\underline{10.2307 / 4047}$ 
Sorvari J. 2006: Two distinct morphs in the wood ant Formica polyctena in Finland: a result of hybridization? Entomologica Fennica 17(1): 1.

Voute A.D. 1942: Classification of factors influencing the natural growth of a population of insects. Acta Biotheoretica 7(1): 99-116. DOI: $10.1007 / \mathrm{bf01603795}$

Voûte A.D. 1951: Zur Frage Der Regulierung der Insekten-Populationdichte durch räuberische Tierarten. Zeitschrift für Angewandte Entomologie 33(1-2): 47-52. DOI: 10.1111/j.1439-0418.1952.tb00652.x

Way M.J. 1963: Mutualism between ants and honeydew-producing Homoptera. Annual Review of Entomology 8: 307-344. DOI: 10.1146/annurev.en.37.010192.002403

Way M.J. \& Khoo K.C. 1992: Role of ants in pest management. Annual Review of Entomology 37: 479-503. DOI: 10.1146/annurev.en.37.010192.002403

Weckwerth W. 1952: Der Kieferspinner und seine Feinde. N Brehm-Bücherei, 40 p.

Wellenstein G. 1942: Die Nonne in Ostpreusen. Monographie Angewandte Entomologie 15: 207-279.

Wellenstein G. 1952: Zur Ernährungsbiologie der Roten Waldameise. Zeitschrift für Pflanzenkrankheiten und Pflanzenschutz 59(11): 430-451.

Wellenstein G. 1954: Die Insektenjagd der Roten Waldameise. Zeitschrift für Angewandte Entomologie 36: 185-217. DOI: 10.1111/j.1439-0418.1954.tb00752.x

Wellenstein G. 1957: Die Beeinflussung der forstlichen Arthropodenfauna durch Waldameisen (Formica rufa gruppe), I. Teil. Zeitschrift für Angewandte Entomologie 41: 368-385. DOI: 10.1111/.14390418.1957.tb01301.x

Wellenstein G. 1959: Möglichkeiten und Grenzen des Einsatzes von Krankheitserregern, Nutzinsekten und Vögeln im praktischen Forstschutz. Forstwissenschaftliches Centralblatt 78(5-6): 150-166. DOI: 10.1007/bf01825421

White T.C.R. 1984: The abundance of invertebrate herbivores on relation to the availability of nitrogen in stressed food plants. Oecologia 63: 90-105. DOI: 10.1007/BF00379790

Whittaker J.B. \& Warrington S. 1985a: An experimental field study of different levels of insect herbivory induced by Formica rufa predation on sycamore (Acer pseudoplatanus) II. Aphidoidea. Journal of Applied Ecology 22: 787-796. DOI: $10.2307 / 2403229$

Whittaker J.B. \& Warrington S. 1985b: An experimental field study of different levels of insect herbivory induced by Formica rufa predation on sycamore (Acer pseudoplatanus) III. Effects on tree growth. Journal of Applied Ecology 22: 797-811. DOI: 10.2307/2403230

Zoebelein G. 1954: Versuche zur Feststellung des Honigtauertrags von Fichtenbeständen mit Hilfe von Waldameisen. Zeitschrift für Angewandte Entomologie 36: 358-362. DOI: 10.1111/j.1439-0418.1954.tb00764.x

Zoebelein G. 1957: Zur Frage des biologischen Nutzwertes der Roten Waldameise. Mitteil. d. Bayer. Staatsforstverw. H. 29.

Érkezett: 2019. február 19.

Közlésre elfogadva: 2019. június 25. 